\title{
Livres, escravos e a construção de um conceito moderno de criminalidade no Brasil Imperial ${ }^{1}$
}

Ricardo Alexandre FERREIRA ${ }^{\circ}$

\begin{abstract}
Resumo: Nas últimas décadas, tem se tornado cada vez mais freqüente a realização de pesquisas que contemplam a elaboração de corpus documentais baseados em registros remanescentes da polícia e da justiça criminal. Na historiografia brasileira, o tema mais significativamente marcado por esse fenômeno foi o da escravidão de africanos e descendentes. Com especial atenção ao processo de construção das fontes analisadas em tais estudos, o presente artigo propõe-se a compreender e interpretar o lugar conferido por membros do Estado Imperial brasileiro a homens e mulheres livres e escravos no cenário mais amplo da construção de um conceito moderno de criminalidade. Para tanto, além dos códigos penais da época, foram analisados os relatórios emitidos pelos ministros da Justiça. A fim de contribuir com o debate especializado, esse estudo assevera que, a despeito da perpetuação da escravidão após a independência política do país, muitas foram as circunstâncias nas quais se manifestaram indistinções entre réus livres e escravos.
\end{abstract}

Palavras-chave: Escravidão; Liberdade; Brasil Imperial; Criminalidade.

Insurreições, sedições e rebeliões foram, durante algum tempo, as formas de transgressão mais freqüentemente abordadas pela historiografia. Em geral, dotadas de grande repercussão, essas ações coletivas conceituadas como crimes em

\footnotetext{
- Doutor em História pela UNESP - Campus de Franca. Departamento de História - Universidade Estadual do Centro-Oeste - Campus Santa Cruz - 85015-430 - Guarapuava - PR - Brasil. E-mail: ricardoferreira.unicentro@gmail.com
} 
códigos de leis figuraram como circunstâncias privilegiadas para o estudo de lutas travadas em nome da transformação das sociedades em que ocorreram ${ }^{2}$. Nas últimas décadas, contudo, pesquisadores de diferentes áreas das humanidades também têm se interessado pela interpretação de outros registros oficiais produzidos para a apuração de eventos tidos como delituosos cuja repercussão muitas vezes circunscreveu-se à região onde foram praticados. Homicídios, ferimentos, roubos e furtos têm sido estudados na perspectiva de uma história do cotidiano que muito contribuiu para a interpretação de "práticas, costumes e estratégias de sobrevivência" (DIAS, 1998) protagonizadas por homens e mulheres que viveram em diferentes épocas e lugares. Entretanto, acompanhando um movimento mais amplo de transformações da justiça criminal em países europeus, já no Brasil do século XIX essa criminalidade miúda passou a interessar cada vez mais às autoridades administrativas estatais. Relatórios periodicamente emitidos por altos funcionários de Estado eram dotados de um tópico obrigatório a respeito do estado da "segurança individual e da propriedade" no Império.

Parte-se, neste texto, do pressuposto de que na esfera da segurança individual ou mesmo no plano mais amplo "dos crimes particulares", como eram conceituados os delitos compreendidos na terceira parte do Código Criminal do Império, não havia, de modo geral, entre as autoridades administrativas, o interesse em diferenciar crimes cometidos por livres, libertos ou escravos. Tal hipótese se apóia em duas ordens de questões que perpassaram, em maior ou menor medida, tanto ministérios da justiça imperiais norteados por tendências políticas mais liberais, quanto por convicções mais conservadoras. De um lado, a preocupação de ministros da justiça e presidentes das províncias com a frágil estabilidade interna do Império implicava em cautela no tratamento de notícias que conjugavam os assuntos "crime" e "escravidão". O tema já causava grandes transtornos à administração quando figurava em papéis oficiais de governo na forma de tentativas de insurreições e assassinatos de senhores e feitores ${ }^{3}$. De outro lado, havia a prática enraizada entre as mesmas autoridades em reunir, em seus relatórios, 
LIVRES, ESCRAVOS E A CONSTRUÇÃO DE UM CONCEITO MODERNO...

escravos, libertos e livres criminosos sob expressões genéricas, tais como: "classes menos favorecidas", "classes inferiores" ou "classes ínfimas da sociedade" ${ }^{4}$. Neste caso, além da sistemática reiteração do estereótipo da vadiagem ${ }^{5}$, é preciso considerar a incapacidade demonstrada pelo Estado, mesmo após as reformas centralizadoras da década de quarenta do século XIX, para a coleta, organização e análise dos registros de criminalidade produzidos em todo o país ${ }^{6}$.

Se este pressuposto é válido, torna-se necessário problematizar a própria noção de criminalidade escrava mais comumente operada pela historiografia especializada, pois além dos assassinatos de senhores, feitores e planejamento de insurreições havia um conjunto amplo de atos tidos como delituosos praticados pelos cativos ao lado ou em condições muito próximas da população livre e liberta. A tentativa que aqui se estabelece é a de compreender e interpretar simultaneamente os fenômenos em questão, quais sejam: a construção de um conceito moderno de criminalidade e o lugar conferido a escravos, libertos e livres neste processo, no âmbito da edificação do Estado Imperial brasileiro. Para tanto, além dos códigos penais da época, foram analisados, durante a elaboração do estudo que fundamenta este artigo, todos os relatórios emitidos pelos ministros da Justiça até a abolição legal do cativeiro no país ${ }^{7}$.

Algumas questões nortearam o desenvolvimento do estudo: Como as autoridades administrativas imperiais concebiam o tema da criminalidade? Como operavam os diversos interesses? O que se entendia por "criminalidade escrava" no âmbito administrativo? Constituiu-se, durante o período escravista, entre as autoridades de governo imperiais a noção de uma "criminalidade livre"? Qual a freqüência do registro de homicídios e ferimentos graves praticados por escravos contra os senhores e seus prepostos, e dos escravos contra a população livre desvinculada do poder senhorial? 
RICARDO ALEXANDRE FERREIRA

\section{A obra e os artífices: os ministros da justiça}

À compreensão das transformações da concepção do problema da segurança individual pelos ministros da justiça é relevante considerar alguns elementos que delineavam a função no cenário institucional do Império. Quem eram os ministros? Quais as suas atribuições? Como o cargo era institucionalmente concebido e delimitado pela Constituição do Império? A incursão pelos caminhos do aparato burocrático da época na busca por algumas respostas para as questões formuladas conduz inicialmente à interpretação do texto constitucional de 1824, elaborada por um dos conhecidos juristas do Império.

Os ministros são não só os primeiros agentes do monarca no exercício do Poder Executivo, mas também partes integrantes ou complementares deste poder; sem que eles referendem ou assinem os atos, não há atos do poder Executivo, não tem força obrigatória. Antes disso são projetos de atos ou atos incompletos, e cujo cumprimento imporia aos executores inteira responsabilidade, pois que procederiam sem ordem ou autorização legítima. São agentes importantíssimos da Coroa, são seus conselheiros administradores, juízes administrativos, tutores dos estabelecimentos pios e de proteção, executores das leis do interesse coletivo ou social encarregados de dirigir e inspecionar os agentes da administração; enfim, são as forças vivas do chefe do Estado para o andamento e bem-estar deste (SÃO VICENTE, 2002: 340).

O Direito Público brasileiro e análise da Constituição do Império, de 1857, obra da qual este excerto é parte, era um dos livros de cabeceira do Imperador Pedro II, conta-se mesmo que o monarca o tinha todo na memória (DUTRA, 2004). Ao mesmo tempo, e não por acaso, o estudo de autoria do jurista José Antônio Pimenta Bueno (1803-1878) constituiu-se na interpretação dos fundamentos jurídicos do Brasil Imperial mais convergente com a leitura legal do Estado elaborada pelo próprio Trono (KUGELMANS, 2002). Ao expor sua interpretação da Constituição de 1824, bem como das modificações por ela 
LIVRES, ESCRAVOS E A CONSTRUÇÃO DE UM CONCEITO MODERNO...

sofrida, o autor explica e sugere alterações ao quadro institucional que compunha o Estado no Império do Brasil de meados dos oitocentos. Sua explanação a respeito da relevância e das atribuições dos ministros de Estado indica alguns dos fundamentos jurídicos que norteavam a função. Entretanto, no decorrer das diferentes fases políticas da história imperial os comprometimentos - algumas vezes alternados durante os anos - com diferentes correntes partidárias ${ }^{8}$, com divergentes concepções e propostas de condução do Estado ${ }^{9}$, integravam fundamentalmente as opiniões dos ministros a respeito do "estado da segurança individual" e de outros inúmeros temas tratados nos relatórios oficiais por eles emitidos.

De maneira semelhante ao que ocorreu com outros ministros da época, Pimenta Bueno ocupou os mais variados cargos ligados aos diferentes poderes que compunham o Estado Imperial. Uma rápida apreciação sobre sua trajetória auxilia na compreensão do caminho que muitas vezes era trilhado até o ministério. O futuro Visconde (1867) e depois (1873) Marquês de São Vicente, cuja origem modesta, os apadrinhamentos e a estreiteza de relações com o Imperador Pedro II são sempre lembrados pelos estudiosos, bacharelou-se na Faculdade de Direito de São Paulo, foi presidente das Províncias do Mato Grosso e do Rio Grande do Sul e atuou como representante diplomático, na condição de Plenipotenciário do Brasil no Paraguai. Na carreira jurídica foi magistrado e ascendeu ao cargo de Desembargador. Em sua longa e típica trajetória ${ }^{10}$ no cenário institucional do Império, Pimenta Bueno também desempenhou as funções de Deputado Provincial, Senador, Ministro e membro do Conselho de Estado.

No final dos anos cinqüenta dos oitocentos, quando publicou O Direito Público brasileiro (...), Pimenta Bueno dava conta da existência de seis secretarias de governo ou ministérios, número que ele aconselhava ser elevado a pelo menos oito, dado a grande quantidade de atribuições de cada ministro. O autor dizia que a Secretaria do Império, por exemplo, estava excessivamente sobrecarregada "não só por grande peso de trabalho, mas pela concentração nela de serviços 
inteiramente heterogêneos entre si" (SÃO VICENTE, 2002: 339). Quase uma década antes, em 1848, o próprio Bueno ocupou a pasta da justiça. Além dele, se sucederam na chefia da Secretaria de Estado dos Negócios da Justiça personagens centrais do cenário político de fases decisivas da história imperial $^{11}$.

Apesar das mudanças ocorridas no decorrer dos anos, as atribuições e competências dos ministros da justiça permaneceram bastante amplas, como alegou Bueno. Em meados dos oitocentos, cabia à secretaria a suspensão das garantias constitucionais nos casos previstos em lei. Estavam também a cargo do ministro a organização e divisão das administrações da justiça civil, comercial e criminal, bem como todo o movimento da magistratura, que envolvia atividades como nomeações, suspensões, promoções e remoções (SÃO VICENTE, 2002: 339). Quando a Graça Imperial era solicitada pelos condenados, na forma de pedidos de anistia, perdão ou comutações de penas, competia ao ministro da justiça intermediar as relações entre o Poder Judiciário e o Poder Moderador $^{12}$. Em caráter especial, a secretaria da justiça acumulava ainda a função de Ministério do Culto, organizando as divisões eclesiásticas, provimentos de bispados e todos os assuntos que representassem a necessidade de relação das ordens e instituições religiosas com o Estado (SÃO VICENTE, 2002).

\section{A crítica conservadora que reforma}

No período compreendido entre a promulgação do Código Criminal do Império, em dezembro de 1830, todo o período regencial (1831-1840), e a primeira década do segundo reinado, o mundo da segurança individual, ou seja, das vinditas, das disputas por divisas que acabavam em tiros e pancadas, dos conflitos matrimoniais e das brigas em ruas, tabernas e festas, ocupava um espaço pequeno nos relatórios emitidos pelos ministros da justiça. Nesta época, a atenção dos membros do 
LIVRES, ESCRAVOS E A CONSTRUÇÃO DE UM CONCEITO MODERNO...

Executivo voltou-se principalmente para o que se entendia mais explicitamente como segurança pública, as notícias a respeito da origem e desdobramentos das revoltas civis e militares, das sedições, rebeliões e insurreições que irromperam nas diversas províncias do país ${ }^{13}$.

Ademais, os ministros alegavam outro problema que impunha a realização de menções rápidas e gerais, a respeito de homicídios e ferimentos nas províncias - a deficiência das comunicações entre as vilas e a capital do Império que impedia o estudo dos padrões da criminalidade individual. A recorrente queixa a respeito da ineficiente integração das autoridades da Corte com as das diferentes províncias figurou na base dos principais argumentos que conduziram às reformas sofridas pela justiça criminal do Império, principalmente a ocorrida no início da década de quarenta.

No relatório do ano de 1837, o então ministro da justiça, Bernardo Pereira de Vasconcelos argumentou que a recorrente reclamação contra a impunidade que se espalhava por todo o território do Império só poderia ser adequadamente avaliada quando os mapas com os perfis de crimes e criminosos fossem produzidos a partir das informações enviadas pelas províncias. Ainda assim, Vasconcelos divulgou números parciais remetidos pelas províncias do Rio de Janeiro, Espírito Santo, Bahia, Alagoas, Piauí, Maranhão, Minas Gerais, Santa Catarina e Goiás. Foi apresentada ao parlamento uma lista simples, sem especificação da participação de cada localidade, na qual os crimes classificados como "contra a segurança da pessoa e vida", ou os chamados crimes de sangue, compunham a metade dentre todas as tipificações ${ }^{14}$. Mesmo sem apresentar elementos mais detalhados a respeito dos crimes e dos criminosos, esse primeiro esforço de produção de um perfil dos delitos praticados era composto por duas características que se perpetuaram nos debates a respeito da criminalidade individual durante todo o período imperial: 1) O maior número de crimes contra a pessoa sobre os que eram cometidos contra a propriedade; 2) A impunidade. 
Bernardo Pereira de Vasconcelos foi uma das personagens emblemáticas no processo de construção do Estado brasileiro, com especial destaque na organização da justiça criminal. Seu nome figurou tanto entre os principais reformadores liberais do período regencial, quanto na construção do chamado "regresso conservador", que conferiu algumas das feições definitivas à conceituação, apuração e julgamento dos crimes no Império do Brasil. Desde O Estadista do Império de Joaquim Nabuco, os estudiosos da história política do Brasil imperial atribuem a Vasconcelos, ainda que com alguma incerteza quanto à autoria, esta auto-descrição:

Fui liberal, então a liberdade era nova no país, estava nas aspirações de todos, mas não nas leis, não nas idéias práticas; o poder era tudo: fui liberal. Hoje, porém, é diverso o aspecto da sociedade: os princípios democráticos tudo ganharam e muito comprometeram; a sociedade, que então corria risco pelo poder, corre agora risco pela desorganização e pela anarquia. Como então quis, quero hoje servi-la, quero salvá-la, e por isso sou regressista. Não sou trânsfuga, não abandono a causa que defendo, no dia de seus perigos, da sua fraqueza; deixo-a no dia em que tão seguro é o seu triunfo que até o excesso a compromete ${ }^{15}$.

Uma década antes de redigir o relatório ministerial acima mencionado, em 1827, Bernardo Pereira de Vasconcelos apresentou à Câmara dos Deputados, então na segunda legislatura após a dissolução da Assembléia Constituinte em 1823, um projeto para a criação de um novo código penal destinado a substituir o Livro V das Ordenações Filipinas. Dias depois, outro deputado, José Clemente Pereira (1787-1854), apresentou uma proposta parcial para o mesmo fim. Os dois textos foram submetidos à apreciação de uma comissão que decidiu não escolher entre eles um vencedor. A comissão, após apontar aspectos mais ou menos favoráveis a cada uma das propostas, optou por combiná-las em um terceiro texto a ser exposto ao debate parlamentar. Diante das negativas dos legisladores, a idéia seguinte foi a de imprimir os dois textos e 
LIVRES, ESCRAVOS E A CONSTRUÇÃO DE UM CONCEITO MODERNO...

distribuí-los aos parlamentares para que se procedesse ao debate. Venceu, por fim, a opinião que resolvia o impasse com a criação de uma comissão composta por deputados e senadores. Essa nova comissão tomou o projeto mais completo por base sem, contudo, abandonar o texto de Clemente Pereira. Dos debates que se seguiram, a tentativa de abolição da pena de morte foi a mais polêmica, mas apenas resultou na extinção da pena última nos casos dos crimes entendidos como de origem política, ficando previsto com base na Constituição de 1824 o recurso do pedido de Graça ao Poder Moderador como última chance aos réus condenados no grau máximo como "homicidas" ou "cabeças de insurreições"16. Foi promulgado o Código Criminal do Império no último mês do ano de 1830, imortalizado, a partir de então, como o código de Bernardo Pereira de Vasconcelos ${ }^{17}$.

Dois anos antes de Vasconcelos assumir o Ministério da Justiça sua obra mais conhecida figurava como um dos mais recorrentes alvos de críticas nas discussões a respeito do tema da criminalidade. Gustavo Adolfo D'Aguilar Pantoja (1798-1867), seu antecessor na pasta da justiça, teceu comentários desabonadores ao, então, novo Código Penal e a seu complemento o Código do Processo Criminal ${ }^{18}$. Os argumentos expostos por Pantoja apoiavam-se na idéia de que a maior causa da impunidade estava entranhada nas deficiências dos próprios códigos criados para apuração dos crimes, julgamento e punição dos criminosos. Sua crítica era ampla, mas atacava fundamentalmente a noção de que o Código Criminal do Império era um avanço em relação às antigas leis portuguesas. $\mathrm{Na}$ opinião do ministro, ambas as legislações se colocavam em extremos indesejáveis.

Se o Livro V das Ordenações dos Filipes pecava por nimiamente severo, os princípios do Código do Processo e do Código Criminal pecam por nimiamente indulgentes, e ainda assim não seria tanto o mal, se todas as Leis fossem, como deviam ser, executadas, e se a organização do Código do Processo não desse lugar a tantas impunidades. Todas as Leis derivam, mais ou menos, das 
máximas e princípios do tempo. Antigamente quase todos os crimes tinham pena capital, ou de cortamento de alguma parte do corpo, pena bárbara e horrível, hoje quase todos os crimes têm penas muito leves, quase todos são afiançáveis, certos mesmo não têm pena alguma ${ }^{19}$.

No relatório ministerial de 1837 Vasconcelos assumiu a existência de problemas pontuais no código elaborado a partir de seu projeto, embora não tenha deixado de mencionar as traduções realizadas e o interesse de juristas europeus pelo texto. Contudo, afirmou que tais problemas eram próprios do desafio envolvido na elaboração de um código que carregava consigo a missão de produzir a "transição rápida de uma Legislação feita em diversas circunstâncias, e tempos, fundada em costumes peculiares, em preconceitos de remotos séculos, para outra acomodada à organização das sociedades modernas" ${ }^{20}$ que, ao nascer, se colocava em desarmonia com muitos interesses, hábitos e costumes do país. Às pequenas reformas sugeridas ao Código Criminal, entre as quais a revisão do artigo que tratava do crime de rebelião, Vasconcelos opôs a necessidade de mudanças profundas na organização da justiça nas comarcas, estabelecida no Código do Processo Criminal de 1832. Suas críticas recaíam, principalmente, sobre a figura do juiz de paz ${ }^{21}$ eleito nas freguesias com competências cíveis, criminais e, em não poucos casos, leigo em assuntos jurídicos. Ainda em seu relatório de 1837, assevera o ministro Vasconcelos:

Muitas vezes, e a experiência o mostra, os Processos organizados pelos Juízes de Paz abundam em nulidades, para cujo suprimento não subministra o Código [do Processo Criminal] meios convenientes. Sendo apresentados ao Juiz de Direito para os sujeitar ao conhecimento do Júri na ocasião da sua reunião, não tem ele o necessário tempo para os rever e examinar. D'aqui tem resultado muitas vezes que na sustentação da pronúncia pelo Júri [decisão pela procedência ou não da acusação contra o réu], apareçam nulidades insanáveis no Processo, para as quais nenhum outro remédio se tem conhecido, senão o da Apelação, 
LIVRES, ESCRAVOS E A CONSTRUÇÃO DE UM CONCEITO MODERNO...

que ocasiona despesas exorbitantes, com grave dano da Justiça, e, não raras vezes, com prejuízo da inocência ${ }^{22}$.

Relembrando a auto-descrição, mencionada páginas atrás, é oportuno ressaltar que nem sempre foi assim. Vasconcelos, juntamente com outros liberais do Primeiro Reinado, foi um entusiasta da Lei de 15 de outubro de 1827 que criou um juiz de paz em cada paróquia, chegando mesmo a redigir um manual destinado a instruir os futuros juízes acerca de suas atribuições. Em sua "Carta aos senhores eleitores da Província de Minas Gerais" de 1828, o então deputado Vasconcelos afirmava que, como bons pais de família, esses juízes procurariam conciliar as partes que intentavam em juízo. "Os pleitos insignificantes e os delitos de pequena entidade serão julgados perante estes escolhidos do povo" (VASCONCELOS, 1999: 112), escreveu ele. Já no final da década de 1830, quando atacava o Juízo de Paz, Vasconcelos, então à frente do chamado "regresso conservador", afirmou ter ocorrido um desvio da função daquela autoridade localmente eleita, em relação ao que foi originalmente previsto na lei de criação do cargo. As críticas de Vasconcelos não paravam no Juízo de Paz, outro elemento do sistema judiciário do Império, fruto das reformas liberais de inícios dos anos 1830, criticado no relatório ministerial de 1837 foi o conjunto de critérios adotados para a escolha dos Conselhos de Jurados. Antes, porém, de passar à crítica do ministro é oportuno explicitar brevemente um pouco da história e funcionamento do júri no Brasil.

Inspirado em modelos de países europeus, principalmente na tradição anglo-saxônica, o júri existiu no Brasil antes mesmo da Independência. As Cortes de Lisboa, por lei de 1821, criaram o júri para atuar nos crimes de liberdade de imprensa. Em junho de 1822 as Cortes também criaram a instituição no Brasil, entretanto, diferente de Portugal, onde os jurados eram eleitos localmente, no Brasil eles eram indicados por corregedores da Coroa portuguesa. A existência e as atribuições do Conselho de Jurados chegaram a ser debatidas na Assembléia Constituinte dissolvida em $1823^{23}$. Estes debates nortearam a elaboração dos 
artigos 151 e 152 da Constituição de 1824, nos quais consta respectivamente:

O poder judicial é independente, e será composto de juízes e jurados, os quais terão lugar assim no civil, como no crime, nos casos e pelo modo que os códigos determinarem [...]. Os jurados pronunciam sobre o fato e os juízes aplicam a lei (SÃO VICENTE, 2002: 593).

Embora tenha havido uma lei datada de 20 de setembro de 1830 que regulou mais detidamente o funcionamento do júri brasileiro, o fez ainda como instituição política. Foi apenas com a promulgação do Código do Processo Criminal de 1832 que o júri tornou-se efetivamente um Tribunal Judiciário com alçada em todos os crimes. Por conseqüência, foi também o Código do Processo que definiu o conjunto de regras para a escolha dos chamados juízes de fato (os jurados). Os jurados eram selecionados nos municípios por vereadores, juízes de paz e párocos entre os habilitados como eleitores na localidade. No sistema que prevaleceu até a reforma de 1841 as referidas autoridades locais excluíam de listas previamente elaboradas nos distritos de paz os nomes que não lhes pareciam gozar de conceito público, inteligência, integridade ou bons costumes. A lista dos selecionados devia ser afixada nas portas das paróquias ou capelas para que fossem encaminhadas reclamações, em razão de nomes ausentes ou indevidamente relacionados. Uma vez por ano as mesmas autoridades se reuniam para revisar a lista, os nomes finalmente apurados eram transcritos em livros, publicados nas portas da Câmara dos Vereadores e na imprensa, transcritos em cédulas e depositados em uma urna que permanecia trancada por duas chaves guardadas pelo presidente da câmara e pelo promotor de justiça. Antes do início de uma sessão de julgamento, sempre presidida por um juiz de direito, eram sorteados sessenta nomes entre os qualificados. Esse grupo era dividido em dois conselhos de jurados. O que atuava inicialmente era chamado de Primeiro Conselho de Jurados ou Júri de Acusação. Para a composição deste primeiro 
LIVRES, ESCRAVOS E A CONSTRUÇÃO DE UM CONCEITO MODERNO...

conselho eram sorteados por um menino, entre os sessenta nomes do sorteio inicial, pelo menos vinte e três jurados. Em uma reunião fechada, após nomearem um presidente e um secretário, esses jurados debatiam a respeito de cada um dos processos criminais em pauta. Caso considerassem necessários esclarecimentos suplementares, os jurados podiam solicitar a presença das testemunhas ou dos representantes de acusadores e acusados. Após todas as deliberações, os jurados definiam se havia ou não provas que motivassem o julgamento. Quando este júri não encontrava evidências contra o acusado o caso era encerrado e a causa declarada improcedente pelo juiz de direito, ficando sem efeito a queixa ou denúncia. De outra forma, quando o primeiro conselho opinava pela procedência da causa dava-se prosseguimento ao processo, com a pronúncia, a determinação da prisão do réu e a produção do libelo acusatório (um documento redigido pela parte acusadora, na maioria dos casos pelo promotor público, contendo os argumentos que sustentavam a culpa do réu). Terminada a formação da acusação e com a anuência do juiz de direito, eram sorteados outros 12 jurados entre os nomes restantes na urna. Essa escolha obedecia ao direito de algumas recusas de nomes pelas partes acusada e acusadora. Este conselho era chamado Segundo Conselho de Jurados ou Júri de Sentença, dele sairia a decisão pela culpa ou pela inocência do réu ${ }^{24}$.

De posse de um esclarecimento mais detalhado a respeito do funcionamento legal da instituição do júri de acordo com as determinações do Código do Processo Criminal de 1832, voltemos à crítica elaborada por Bernardo Pereira de Vasconcelos contra a instituição. De acordo com o ministro:

O derramamento de nossa população em um território extenso, e pouco povoado, torna em muitos lugares sumamente difícil a reunião de sessenta jurados, que devem concorrer em cada Sessão. O mesmo Código [do Processo Criminal] supõe a existência de Municípios, onde se não encontra esse número, e por isso admite a convocação daqueles indivíduos, que como indignos excluíra para exercer as funções de Jurados, como se a 
falta de pessoas dignas tornasse tais aquelas, que o não eram; ou como se o Cidadão, que habita lugares menos povoados, gozasse de menos garantias, que os outros! Por esta maneira entregou o nosso Código [do Processo Criminal] a honra, a fortuna, e a vida desses Cidadãos àquela mesma incapacidade, ou indignidades, que é repelida nos Municípios mais populosos ${ }^{25}$.

Tais argumentos de Vasconcelos contra os juízes de paz e o júri não eram opiniões isoladas, pois traduziam interesses e convicções políticas que acabaram por se concretizar na mudança sofrida pelo Código do Processo Criminal em $1841^{26}$. A reforma criou os cargos de subdelegado, delegado e chefe de polícia, todos indicados pelo Executivo, os quais substituíram, a partir de então, o juiz de paz em quase ${ }^{27}$ todas as suas funções policiais. O Primeiro Conselho de Jurados ou Júri de Acusação foi extinto. A formação da culpa nos processos criminais passou à competência dos delegados de polícia que ao final da inquirição de testemunhas remetia os processos aos juizes municipais ${ }^{28}$, também indicados pelo governo central dentre bacharéis formados em direito. Os juízes municipais revisavam os processos, sustentavam ou revogavam a decisão pela procedência da culpa contra o acusado feita pelos delegados de polícia, para finalmente enviar os autos ao juiz de direito, quem, a partir de então, realizava a pronúncia e presidia o processo até o julgamento, onde um único conselho de jurados resolvia pela culpa ou inocência do réu.

A lei de 1841 também mudou os critérios para a escolha dos membros do júri. Se em apenas um Termo não fosse possível qualificar 50 pessoas aptas para serem jurados reunir-se-iam duas ou mais localidades. As listas iniciais dos candidatos a jurados passaram a ser produzidas pelos delegados de polícia, que deveriam arrolar todos os indivíduos moradores na sua jurisdição que fossem eleitores, soubessem ler e escrever e possuíssem rendimentos anuais:

[...] por bens de raiz ou emprego público 400\$000 nos Termos das

Cidades do Rio de Janeiro, Bahia [sic], Recife e São Luiz do 
LIVRES, ESCRAVOS E A CONSTRUÇÃO DE UM CONCEITO MODERNO...

Maranhão; 300\$000 nos Termos das outras Cidades, e 200\$000 em todos os mais Termos. Quando o rendimento provier do comércio ou indústria, deverão ter o duplo. Exceptuam-se os Senadores, Deputados, Conselheiros e Ministros de Estado, Bispos, Magistrados, Oficiais de Justiça, Juízes Eclesiásticos, Vigários, Presidentes e Secretários dos Governos das Províncias, Comandantes das Armas e dos Corpos de $1^{a}$ linha ${ }^{29}$.

Uma cópia da lista era afixada na porta da paróquia local e outra remetida ao juiz de direito em época pré-determinada de todos os anos. As listas ainda eram submetidas a juntas revisoras, compostas pelo juiz de direito, pelo promotor público e pelo presidente da câmara municipal, em sessões públicas. Essas juntas deveriam atender reclamações, corrigir erros, inserir e excluir nomes, até que a listagem fosse registrada em livros apropriados. Uma vez terminada a lista geral, os nomes nela contidos seriam transcritos em cédulas e depositados em uma urna trancada por três chaves que ficariam em poder dos três membros da junta revisora ou de seus suplentes. Os livros com os nomes dos jurados, bem como a urna contendo as cédulas eram guardados pela Câmara Municipal que se responsabilizava por fornecê-los nos dias de trabalho do júri ${ }^{30}$.

Entretanto, mesmo com as reformas o sistema do júri continuou dividindo a opinião de juristas e políticos. A cada novo gabinete ministerial e, em alguns casos, a cada novo relatório apresentado à Assembléia Geral, os ministros da justiça atribuíam à instituição do júri grande parte da responsabilidade pela impunidade dos acusados pela prática de crimes. Quando as denúncias de fraude não se dirigiam diretamente à escolha dos jurados, identificavam-se parcialidades dos Juízes de Direito e dos "juízes de fato" atribuídas à cooptações e intimidações promovidas por chefes locais que não se interessavam pela condenação deste ou daquele réu. Vejamos o que disse a esse respeito, quase dez anos após a reforma de 1841, o também conservador Eusébio de Queiroz, ministro da justiça responsável pela apresentação do relatório de 1849 à Assembléia Geral na segunda sessão da oitava legislatura: 
Não é possível dissimular, Senhores, o grande número de atentados cometidos contra a segurança individual; não há uma só província que não tenha contribuído com seu contingente para a história de assassinatos e violências, ultimamente perpetrados, que seria longo referir-vos. A pouca ou nenhuma força de que podem dispor as autoridades policiais, o desleixo e negligência de algumas, a conivência de outras, e mais que tudo a impunidade que acoroçoa os criminosos, são as principais causas a que se devem atribuir tantos e tão atrozes assassinatos, como os que têm chegado ao conhecimento do Governo. Nos sertões, onde abundam os crimes desta natureza, ou não há julgamentos, ou representa-se uma farsa ridícula com aparências judiciais em que as decisões são de antemão conhecidas ou porque os juízes são cúmplices, ou porque são fracos e subscrevem as sentenças que lhes impõem os potentados do lugar ${ }^{31}$.

Apesar da persistência de problemas anteriores, a lei da reforma do Código do Processo de 1841 definiu quase todas as bases sobre as quais funcionou a justiça criminal brasileira até o final do Império, sem grandes alterações. Nesse sentido, argumenta Joaquim Nabuco ao discutir as atuações de liberais e conservadores à frente dos Gabinetes Ministeriais no contexto das reformas judiciárias:

O Código do Processo [de 1832] havia feito dos juízes de paz o elemento ativo da justiça criminal: a reação conservadora substituíra esse mecanismo popular pela polícia, que foi centralizada nas capitais, com a criação dos chefes [de polícia] e unificada nas mãos do ministro da justiça. Quando se votou a lei que assim transformara completamente o sistema da justiça, o partido Liberal protestou em nome das conquistas populares da Regência, e levantou-se em armas em São Paulo e Minas. No governo, porém, de 1844 a 1848, ele nunca seriamente pensou em reformar a lei de 1841; fez algumas tentativas sem insistência (NABUCO, 1949, vol I: 194).

No que concernia especificamente à justiça criminal, foi apenas em 1871 que se realizou nova e última mudança legal 
LIVRES, ESCRAVOS E A CONSTRUÇÃO DE UM CONCEITO MODERNO...

significativa durante o Império ${ }^{32}$. Efetivada no mesmo ano que a "Lei do Elemento Servil", no conjunto da qual ficou mais conhecida a "Lei do Ventre Livre", a Reforma Judiciária levada a termo pelo Ministro Francisco de Paula de Negreiros Sayão Lobato, formalizada pela lei de 20 de setembro de 1871, atendia a algumas das propostas de reforma sugeridas por antigos projetos que se sucederam à reforma de $1841^{33}$. No plano criminal, destacou-se o fim da sobreposição de competências policiais e judiciárias nas mesmas autoridades. De acordo com a reforma de 1871, os crimes afiançáveis, tais como os ferimentos leves, não eram mais levados ao tribunal do júri, ficavam restritos à competência policial. Por sua vez, os delegados de polícia perderam a competência para a formação da culpa nos processos criminais que apuravam crimes considerados graves, tais como o homicídio. Essa atribuição passou à alçada exclusiva dos juízes municipais, os quais submetiam suas decisões aos juízes de Direito ${ }^{34}$.

Cada uma dessas reformas culminou na alteração dos destinos de muitas pessoas, fossem elas, membros da polícia e da justiça, ou mesmo do conjunto geral dos habitantes do Império, homens e mulheres, livres e escravos, criminosos ou não.

\section{Criminosos livres e criminosos escravos}

No início dos anos 1840, e ainda com a repetida alegação da ineficácia das leis figurando entre os principais motivos para a perpetuação da impunidade, o ministro da justiça Francisco Ramiro D'Assis Coelho, no relatório relativo ao ano de 1839, reiterou argumentos e críticas de seus antecessores e apresentou à Assembléia Geral a relação nominal dos réus sentenciados à pena de morte, que recorreram ao Poder Moderador. No documento constam 62 réus, todos do sexo masculino. Dentre eles, a maior parte, 28, eram provenientes do município da Corte e de outros tribunais da Província do Rio de Janeiro, 9 foram enviados por Minas Gerais, 8 pela Província do 
Ceará, 5 pela Bahia, 3 pelo Maranhão, 3 por São Paulo, 2 pela Paraíba, 2 por Pernambuco, 1 por Goiás e 1 por Santa Catarina. Do total de réus (62) que apelaram das sentenças apenas onze tiveram suas penas comutadas para: prisão perpétua, galés perpétuas, desterro (para fora da comarca) e degredo (para outras partes do Império). O ministro enfatizou que a maior parte (64,5\%) dos pedidos de clemência foi negada e os réus definitivamente condenados à execução na forca, conforme as disposições do Código Criminal. Entre os nomes dos 40 réus que morreriam no patíbulo é possível identificar 11 escravos. Outros quatro cativos tiveram as penas comutadas e nenhum figurou entre os 11 réus perdoados ${ }^{35}$.

Francisco Ramiro D'Assis Coelho não foi o primeiro ministro da justiça a divulgar as execuções, pois essa era uma atribuição da pasta. Entretanto, ostentar enforcamentos como prova de controle dos distúrbios provinciais, eficiência das leis e medida contra a impunidade parece não ter sido uma estratégia de unânime aceitação frente ao problema da criminalidade. Outros ministros preferiram adotar em seus relatórios distintas estratégias de explicação para o problema da criminalidade no Império, estreitamente vinculadas ao ataque à estrutura judiciária então vigente.

No início de 1841, o ministro da justiça Paulino José Soares de Souza, futuro Visconde do Uruguai, adotou em seu relatório a respeito do ano anterior uma explicação para a criminalidade fundada nas diferenças existentes entre as populações do litoral e as que viviam no interior das províncias. Segundo o ministro, separados uns dos outros e das povoações por enormes distâncias cobertas por serras e matas, sem instrução moral e religiosa, os habitantes do interior viviam fora do alcance do governo e estavam imbuídos de uma mal entendida noção de liberdade:

[...] os homens bons que habitam esses lugares vêem-se forçados, em defesa própria, a oprimir para não serem oprimidos; constituem-se pequenos centros de força, a que se aglomeram os perseguidos, que depois a vingança torna também 
LIVRES, ESCRAVOS E A CONSTRUÇÃO DE UM CONCEITO MODERNO...

perseguidores. Essa força cresce na razão dos acontecimentos quotidianos, e procurando cada um obter maior grau de preponderância e tornar-se temido para ser respeitado, abre a sua proteção ao maior número de facinorosos e turbulentos. Como as justiças territoriais são o resultado das eleições, recaem estas muitas vezes em pessoas que deveriam expiar nas prisões uma longa carreira de crimes, e que reforçadas com a autoridade dos cargos se tornam pequenos potentados, de fato independentes do Governo, e acima de toda a responsabilidade. Dispondo nas eleições de grande número de votos, não é raro que encontrem proteções valiosas e decididas. Tal é o estado de muitos dos nossos sertões ${ }^{36}$.

Quando redigiu o mencionado relatório Paulino cerrava fileiras ao lado de Bernardo Pereira de Vasconcelos na chefia do Partido Conservador ${ }^{37}$. Apesar de manifestarem temperamentos distintos, os dois políticos/juristas tornaram-se amigos íntimos. Conta-se que Vasconcelos pedia a Paulino discursos para serem lidos no Senado e, até mesmo, empréstimos em dinheiro. Contudo, diferente de Vasconcelos, Paulino não defendeu a escravidão. "Na questão do tráfico, reconhecia o dano que sua abolição traria para a indústria nacional, mas as razões de Estado e a pressão externa, física e moral, lhe pareciam falar mais alto" (CARVALHO, 2002: 40). No que se refere ao problema do controle dos registros de criminalidade produzido nas províncias, da mesma maneira que seus antecessores no ministério, Paulino reclamou da ausência de uma estatística criminal para todo o Império. De acordo com o ministro: "apenas ultimamente [1841] poucos presidentes tem empreendido coligir [...] alguns dados em seus relatórios, mas, além de poucos, são seus trabalhos baseados em diverso plano, e feitos com diversas vistas, pelo que a sua falta de uniformidade os torna pouco aproveitáveis" ${ }^{38}$.

Dois anos depois, em 1844, o ministro Manuel Alves Branco, autor de grande parte do projeto original do Código do Processo Criminal de 1832, "ferrenho inimigo" de Bernardo Pereira de Vasconcelos (DUTRA, 2004: 39), tentou levar abaixo a argumentação de, seu também adversário político, Paulino José 
RICARDO ALEXANDRE FERREIRA

de Souza a respeito da civilidade das regiões litorâneas em detrimento dos sertões. Segundo Branco:

[No que toca] aos crimes de natureza individual, cumpre-me dizer, que nesta parte ainda é mui lastimoso o nosso estado. Fatos horríveis dos mais bárbaros atentados são ainda muito freqüentes em todas as Províncias do Império, sem excetuar mesmo (coisa incrível) a Província do Rio de Janeiro, sem dúvida a mais civilizada, de população mais concentrada, e a face das autoridades numerosas, e das Supremas do Império ${ }^{39}$.

Em meados da década de quarenta, os ministros já manifestavam na Assembléia Geral a opinião de que havia alguma melhora na situação das rebeliões nas províncias, que marcaram fundamentalmente o período das regências e o início do reinado de Pedro II. No entanto, se a tranqüilidade pública não era mais o único foco de atenção em pauta, pelo menos no plano das afirmações oficiais de governo, a segurança da pessoa e da propriedade passava paulatinamente a figurar no plano mais elevado das preocupações do Executivo. Alguns crimes, em especial, começavam a ganhar relevo. Dentre eles, destacava-se a perpetuação de delitos entre famílias ${ }^{40}$. No relatório de 1846 o Ministro José Joaquim Fernandes Torres menciona a continuação dos conflitos entre as famílias Militão e Guerreiro na Bahia, cuja sucessão alternada de assassinatos já envolvia bandos armados com duas dezenas de pessoas. Além dessas ocorrências, o ministro destacou a generalizada prática de crimes "puramente individuais" em todas as províncias, principalmente nas regiões mais remotas onde, segundo ele, "as povoações ainda pouco ilustradas tem como recurso a prática brutal do punhal e do bacamarte, e não as leis, para vingar-se de seus inimigos pessoais ${ }^{41 "}$.

José Antônio Pimenta Bueno, então ainda entre os liberais, assumiu o Ministério da Justiça na segunda metade da década de quarenta e ficou encarregado de apresentar o relatório relativo ao ano de 1847. O ministro asseverou que o problema da segurança pessoal e da propriedade individual se avultava, 
LIVRES, ESCRAVOS E A CONSTRUÇÃO DE UM CONCEITO MODERNO...

principalmente no interior de algumas províncias no norte do país. Na Bahia permanecia o conflito familiar entre Militão e Guerreiro com a multiplicação de homicídios e enfrentamentos. No norte da província de Alagoas, diversos fugitivos da justiça acusados por assassinatos e outros delitos sobressaltavam os povoados. O ministro destacou o nome de Vicente de Paula que, a partir das matas de Jacuípe, e junto com outros homens, realizava façanhas, invadia vilas, festas públicas, praticava assaltos e diversos delitos narrados nas páginas dos relatórios dos chefes de polícia. Vicente de Paula tornou-se a cada dia mais conhecido e seu bando teria alcançado alguns povoados das regiões limítrofes entre Alagoas e Pernambuco.

A essa altura, nos anos finais da década de quarenta, as estatísticas criminais não eram inexistentes, mas continuavam a ser vistas com reservas pelos ministros, o que tornava corrente nos relatórios a narrativa de alguns crimes considerados atrozes. Em 18 de dezembro de 1847, na Província do Ceará, foram assassinados, na fazenda Cana Brava, João Ribeiro de Mello, dois filhos menores, uma filha, uma afilhada, um vaqueiro e uma agregada da casa. Os assassinos teriam sido vários homens chefiados por Raimundo Gadelha, Lourenço Gadelha e José Bezerra. Horas após o crime um dos filhos da vítima seguiu com homens armados à procura dos assassinos de sua família, matou o principal chefe Raimundo Gadelha e outros dois homens. Uma escolta armada foi até a Província do Piauí prender José Bezerra, terceiro acusado pelas mortes no Ceará. Contrariando a autoridade do delegado local, a escolta prendeu Antonio Bezerra, José Bezerra e um escravo. Tão logo o grupo atravessou a divisa da Província do Ceará, José Bezerra foi assassinado por pessoas que se diziam vingadoras da morte da família de João Ribeiro de Melo $^{42}$.

Aos poucos, os chamados facinorosos, identificados com nome, sobrenome e o epíteto de "célebres homicidas e ladrões", perseguidos durante anos pelas autoridades policiais, passaram a dividir as páginas dos relatórios oficias de Estado não só com as vinganças desencadeadas por conflitos eleitorais e familiares, mas também com assassinatos cometidos por maridos traídos, 
companheiros de trabalho e cateretês envolvidos em rixas e desafios, fossem eles livres ou escravos. É verdade que esses crimes não eram inicialmente apresentados em relatos detalhados, pois, de maneira geral, até meados dos oitocentos, os ministros preferiam narrar na Assembléia Geral os crimes considerados de maior gravidade e repercussão. Mas, eles estavam presentes em menções gerais ao avultado número de homicídios de diversas naturezas que se espalhavam por todas as províncias do Império comunicados pelos chefes de polícia e arrolados nas estatísticas criminais e judiciárias.

Entre o início da década de cinqüenta e o ano 1862, sob a égide da política de conciliação ${ }^{43}$, as estatísticas criminais passaram a seguir a padronização tão reclamada. Neste aspecto em particular, apesar das permanentes críticas a respeito de mapas parciais ou não enviados pelas províncias, a nova estrutura policial e judiciária estabelecida pela reforma de 1841 dava mostras de uma ligação mais efetiva na integração dos municípios com as sedes das províncias e destas com o Ministério da Justiça. Entretanto, a maior preocupação com a segurança individual e a organização da estatística parece ter resultado numa dor de cabeça adicional às autoridades administrativas. A análise dos dados enviados pelos presidentes de província ao Ministério da Justiça nos anos cinqüenta indicava que os números da criminalidade individual cresciam vertiginosamente. Ano a ano mais e mais homicídios e ferimentos chegavam ao conhecimento da polícia e da justiça. Vez por outra, a estatística era usada pelas autoridades do Executivo para sustentar a opinião da manutenção ou de um ligeiro decréscimo do número de "crimes contra a pessoa" entre um ano e outro.

A comparação entre os números de 1855 e 1854, período em que a quantidade de homicídios apontada pelos dados coligidos nas províncias caiu quase pela metade, ficou a cargo do primeiro ministro da justiça do período da conciliação partidária, José Thomaz Nabuco de Araújo, um dos maiores entusiastas da quantificação. Segundo seu filho Joaquim Nabuco, as propostas de reforma do judiciário elaboradas por 
LIVRES, ESCRAVOS E A CONSTRUÇÃO DE UM CONCEITO MODERNO...

Nabuco de Araújo seguiam o traço marcante da personalidade do estadista, pois se originavam do resultado da identificação de falhas e lacunas observadas durante sua experiência como: advogado, juiz e ministro. Entre estas falhas, Nabuco de Araújo conferia especial atenção à ausência da quantificação dos delitos e dos dados a respeito do andamento dos processos criminais. Especificamente com relação a esse tema nos conta o filho biógrafo, citando o próprio pai:

'Não existindo entre nós outros registros criminais senão os livros dos culpados, livros disseminados por inúmeros cartórios sem garantia alguma de autenticidade, dos quais com dificuldade e grande despesa os cidadãos tiram folhas corridas para mostrarem-se livres de culpa' (são palavras suas), nomeia ele uma comissão de advogados, Perdigão Malheiro, sendo relator, para organizar um projeto instituindo no Império os registros criminais, à imitação dos da França, reproduzidos em Portugal, na Itália e em outros países. '... Esses registros criminais, dizia ele, além de serem um elemento da estatística prestam uma prova fácil das reincidências e um meio cognoscitivo pronto para saber-se o passado dos acusados'. [...] Assim como os registros criminais, é de Nabuco o primeiro ensaio de estatística criminal, decreto $\mathrm{n}^{\circ} .3572$ de 30 de dezembro de 1865, mandando executar o regulamento da Estatística Policial e Judiciária (NABUCO, 1949, vol. II: 351-352).

Ainda assim, mesmo Nabuco de Araújo via os dados quantitativos com cautela. Em seu relatório ministerial o estadista alertou os legisladores que seria uma temeridade a inferência de conclusões a partir dos números de crimes relativos a um único ano, principalmente, segundo ele, do ano de 1855 quando uma epidemia de cólera-morbus "infundiu por toda parte o terror e destruiu muitos algozes e vítimas, acometendo principalmente a classe que fornece à estatística criminal o maior número deles ${ }^{44 "}$. A estatística trazia a criminalidade individual à ordem do dia, sem, contudo, diferenciar livres de escravos ou bandidos afamados e reincidentes de pessoas que 
recorreram a soluções violentas para seus desentendimentos cotidianos.

Terminada, contudo, a fase da conciliação partidária tornou-se mais difícil, mesmo para os contemporâneos, empreender nos relatórios ministeriais um estudo sistemático da progressão das estatísticas criminais e judiciárias. Em geral, cada novo ministro da justiça de um novo Gabinete adotava novas estratégias de coleta, organização e apresentação dos dados recolhidos nas comarcas. Muitos lamentavam não poder contar com os dados por atrasos, ausências ou a existência apenas de números parciais. Acresce que o mais completo levantamento demográfico do Império só foi levado a termo em $1872^{45}$. Até então, sem os números da variação populacional do país tornava-se quase impossível compreender o aumento ou a diminuição dos números de crimes, embora os ministros sempre tenham tentado chamar a atenção para alguns temas que estariam diretamente vinculados com a elevação dos números de delitos violentos registrados e processos julgados nas comarcas do Império.

Contudo, os padrões gerais dos crimes apresentados pelos ministros a cada novo relatório se perpetuaram durante as décadas dos oitocentos. As características mais marcantes da época do primeiro esforço estatístico aqui mencionado, da década de 30 , permaneciam inalteradas. Refletindo o padrão mais comum de criminalidade estudada a partir de processos criminais em diferentes regiões no mesmo período, o número de delitos chamados violentos (ferimentos e homicídios) continuou a se sobrepor aos que chegavam ao conhecimento das autoridades a respeito dos danos e subtrações da propriedade ${ }^{46}$.

Quanto aos perfis de criminosos, inicialmente as estatísticas não separavam os delitos cometidos por escravos do restante da população. Apenas no item "Infração de Posturas" essa distinção era feita, mantendo-se durante os anos um número muito superior de réus livres em relação aos que se encontravam no cativeiro. Em alguns relatórios ministeriais da década de setenta foram quantificados os réus que responderam a julgamento, dentre eles mais de noventa por cento eram livres. 
LIVRES, ESCRAVOS E A CONSTRUÇÃO DE UM CONCEITO MODERNO...

Entretanto, mais recorrentemente do que ocorria nos mapas criminais do Ministério da Justiça, na Província de São Paulo o número de réus escravos era, em alguns casos, divulgado separadamente dos réus livres e libertos. Ainda assim, entre os processos julgados nas comarcas de São Paulo em 1851 o pequeno número de réus cativos $(11,1 \%)^{47}$ em relação aos livres ratificou a tendência entre os números apurados para o país como um todo. Nos anos seguintes, mesmo considerando-se que ora constavam estatísticas criminais preparadas pela secretaria de polícia, ora o número de processos-crime julgados pelos tribunais do júri de cada comarca, a participação cativa manteve-se em torno de dez por cento do total. Anexada ao relatório de 1871, uma listagem intitulada "Crimes cometidos na Província de São Paulo em 1870"48 apresenta um total de 389 réus listados, dos quais 26 (6,68\%) eram cativos. Com base nestas informações é possível inferir que independentemente das variações locais entre a população livre e escrava, mantevese a tendência geral na província dos escravos comporem uma pequena fração do total de réus. Ainda no relatório de 1871, foi apresentado um recenseamento dos "presos existentes nas cadeias da Província de São Paulo em 1870"49. A listagem totalizou 292 encarcerados, dos quais 114 eram escravos. Num período em que os ataques violentos à autoridade senhorial em São Paulo sofreram um grande incremento, o documento menciona $52(45,6 \%)$ cativos condenados pelos crimes da Lei de 10 de junho de 1835, ou seja, crimes contra os senhores, seus prepostos ou familiares deles. Todos os demais escravos 62 $(54,4 \%)$ estavam presos por crimes cometidos contra outros cativos e pessoas livres distintas de seus proprietários, feitores e administradores, ou seja, estavam no âmbito dos crimes cometidos por escravos que as autoridades administrativas simplesmente agrupavam à criminalidade atribuída à população em geral, pois eram ações motivadas por razões semelhantes às dos crimes cometidos por pessoas livres.

Nem só de números, contudo, eram compostos os relatórios. Após apresentar as tendências apuradas na estatística criminal, as autoridades provinciais passavam a HISTÓRIA, São Paulo, 28 (2): 2009 
atribuir causas aos problemas com a segurança individual. Predominavam as motivações consideradas pelas autoridades como frívolas e ocasionais, sempre acompanhadas de menções ao corriqueiro porte de armas de fogo e facas, à prática de jogos, ao abuso de bebidas alcoólicas e, principalmente, às disputas envolvendo amantes. Em todas estas situações havia a presença de escravos ${ }^{50}$.

No entanto, à medida que o país se desenvolvia, a população crescia e os problemas com a substituição da mão-deobra se tornavam incontornáveis, a necessidade de deslocar cativos do Nordeste do Brasil para as lavouras cafeeiras do Rio de Janeiro e de São Paulo, significativamente intensificada após o encerramento do tráfico transatlântico $(1850)^{51}$, convergiu com o aumento das tensões nas regiões de lavouras exportadoras, e com o incremento no registro de ferimentos e assassinatos praticados pelos cativos contra seus senhores e feitores esses crimes cometidos por escravos acabaram tomando o maior vulto no debate historiográfico especializado ${ }^{52}$.

A redução do âmbito da criminalidade escrava aos delitos cometidos contra o sistema escravista é plenamente compreendida no processo de construção do Estado no Império do Brasil. No entanto, mesmo nos relatórios oficias é possível verificar - nas estatísticas ou em curtos relatos de crimes informados pelos chefes de polícia - a presença de cativos cometendo ações tidas como delituosas em distintas circunstâncias. Para que possamos avançar na compreensão do binômio "criminalidade e escravidão" no Brasil imperial é necessário considerar as diferentes formas de ação dos escravos no cotidiano de luta contra a condição de cativo, ainda que essa luta se manifestasse no desejo de ocupar espaços tidos como próprios da população livre.

\section{Referências Bibliográficas}

ALGRANTI, L. M. O feitor ausente: estudo sobre a escravidão urbana no Rio de Janeiro. Petrópolis: Vozes, 1988. 
LIVRES, ESCRAVOS E A CONSTRUÇÃO DE UM CONCEITO MODERNO...

ALVES JÚNIOR, T. Anotações teóricas e práticas ao Código Criminal. Rio de Janeiro: Francisco Luiz Pinto \& C. editores, 1864. 4 tomos.

AZEVEDO, C. M. M. de. Onda negra, medo branco: o negro no imaginário das elites - século XIX. Rio de Janeiro: Paz e Terra, 1987.

BOTELHO, T. R. População e nação no Brasil do século XIX. 1998. 248 f. Tese (Doutorado em História) - Faculdade de Filosofia, Letras e Ciências Humanas, Universidade de São Paulo, São Paulo.

CARVALHO, J. M. de. Construção da ordem: a elite política imperial; Teatro de sombras: a política imperial. 2.ed. Rio de Janeiro: Editora UFRJ, Relume-Dumará, 1996.

In: VASCONCELOS, B. P. de. Bernardo Pereira de Vasconcelos. São Paulo: Ed. 34, 1999.

2002. . In: URUGUAI, V. do. Visconde do Uruguai. São Paulo: Ed. 34,

CERQUEIRA LEITE, Beatriz Westin de. A reforma judiciária de 1871 e sua discussão no Senado do Império. História, São Paulo, v.1, p. 61-75, 1982.

CHALHOUB, S. Trabalho, lar e botequim: o cotidiano dos trabalhadores no Rio de Janeiro da belle époque. São Paulo: Brasiliense, 1986.

- Visões da liberdade: uma história das últimas décadas da escravidão na Corte. São Paulo: Companhia das Letras, 1990.

. Cidade Febril: cortiços e epidemias na Corte imperial. São Paulo: Companhia das letras, 1996.

DIAS, M. O. L. da S. Hermenêutica do quotidiano na historiografia contemporânea. Projeto História. São Paulo, (17), nov. 1998.

DUTRA, P. Literatura jurídica no Império. $2^{\mathrm{a}}$ ed. rev. e ampl. Rio de Janeiro: Padma, 2004.

FERREIRA, R. A. Senhores de poucos escravos: cativeiro e criminalidade num ambiente rural (1830-1888). São Paulo: Editora UNESP, 2005.

. Crimes em comum: escravidão e liberdade no extremo nordeste da Província de São Paulo (Franca 1830-1888). 2006. Tese (Doutorado em História). Faculdade de História Direito e Serviço Social, Universidade Estadual Paulista, Franca.

. "O tronco na enxovia: escravos e livres nas prisões paulistas dos Oitocentos. In. BRETAS, M. L.; COSTA, M.; NUNES, C. N.; SÁ NETO, F. de. (Org.). História das Prisões no Brasil. 2 v. 1 ed. Rio de Janeiro: Rocco, 2009.

FLORY, T. Judge and jury in imperial Brazil, 1808-1871: social control and political stability in the new State. Austin: University of Texas Press, 1981. 
GRAHAM, R. Nos tumbeiros mais uma vez? O Comércio interprovincial de escravos no Brasil. Afro-Ásia. n. 27, 2002.

KUGELMANS, E. In. SÃO VICENTE, J. A. P. B., marquês de. José Antônio Pimenta Bueno, marquês de São Vicente. São Paulo: Ed. 34, 2002.

MACHADO, M. H. P. T. Crime e escravidão: trabalho, luta e resistência nas lavouras paulistas 1830-1888. São Paulo: Brasiliense, 1987.

- O Plano e o pânico: os movimentos sociais na década da abolição. Rio de Janeiro: UFRJ, EDUSP, 1994.

MARSON, I. A. O Império do progresso: a revolução praieira em Pernambuco. São Paulo: Brasiliense, 1986.

. "O Império da revolução: matrizes interpretativas dos conflitos da sociedade monárquica". In: FREITAS, Marcos Cezar (org.). Historiografia brasileira em perspectiva. São Paulo: Contexto, 1998, p. 73-10.

MATTOS, H. M. Das cores do silêncio: os significados da liberdade no sudeste escravista - Brasil século XIX. Rio de Janeiro: Nova Fronteira, 1998.

MATTOS, I. R. de. O tempo Saquarema: a formação do Estado imperial. $4^{\mathrm{a}}$ ed. Rio de Janeiro: ACCESS, 1994.

NABUCO, J. Um Estadista do Império. São Paulo: IPÊ - Instituto Progresso Editorial S.A., 1949, 4 tomos.

OLIVEIRA, C. H. de S. "Da natureza do Poder Moderador e a memória do Conselheiro Zacarias de Góis e Vasconcelos". In: VASCONCELOS, Zacarias de Góis e / organização e introdução de Cecília Helena de Salles Oliveira. Zacarias de Góis e Vasconcelos. São Paulo: Ed. 34, 2002.

. O Poder Moderador no segundo reinado - mediações entre

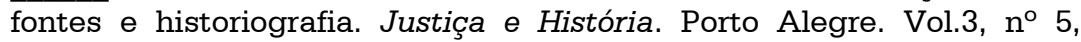
p.141-160, 2003.

PIMENTEL FILHO, J. E. A produção do crime: violência, distinção social e economia na formação da província cearense. 2002. Tese (Doutorado em História) - Faculdade de Filosofia, Letras e Ciências Humanas, Universidade de São Paulo, São Paulo.

REIS, J. J. Rebelião escrava no Brasil: a história do levante dos malês em 1835. Edição revista e ampliada. São Paulo: Companhia das Letras, 2003.

RIBEIRO, J. L. No meio das galinhas as baratas não têm razão: a Lei de 10 de junho de 1835: os escravos e a pena de morte no Império do Brasil: 1822-1889. Rio de Janeiro: Renovar, 2005. 
LIVRES, ESCRAVOS E A CONSTRUÇÃO DE UM CONCEITO MODERNO...

SÃO VICENTE, J. A. P. B., Marquês de. José Antônio Pimenta Bueno, marquês de São Vicente. São Paulo: Ed. 34, 2002.

SLEIMAN, A. "À nação independente, um novo ordenamento jurídico: a criação dos Códigos Criminal e do Processo Penal na primeira década do Império do Brasil". In. RIBEIRO, G. S. Brasileiros e cidadãos: modernidade política 1822-1830. São Paulo: Alameda, 2008.

SOUZA, L. de M. e. Desclassificados do ouro: a pobreza mineira no século XVIII. $4^{a}$ ed.rev. e ampl. Rio de Janeiro: Edições Graal, 2004.

URUGUAI, V. do. Visconde do Uruguai. São Paulo: Ed. 34, 2002.

VASCONCELOS, Bernardo Pereira. Bernardo Pereira de Vasconcelos. São Paulo: Ed. 34, 1999.

VELLASCO, I. de A. As seduções da ordem: violência, criminalidade e administração da justiça: Minas Gerais - século 19. São Paulo: ANPOCS e Bauru: EDUSC, 2004.

FERREIRA, Ricardo Alexandre. Freemen, slaves and the construction of a modern concept of criminality in Brazil Imperial. História, v.28, n.2, p.339-376, 2009.

Abstract: In the last decades, has become common, building sources based in police and judicial records in historic research. In Brazilian historiography the issue most significantly marked by this phenomenon was the enslavement of Africans and their descendants. With special attention to the construction of the sources analyzed in such studies, this article aims to understand and interpret the role given by members of the Imperial Brazilian State to the freeman and slave in the picture of building a modern concept of criminality. To reach this objective, besides the penal codes, we analyzed the reports issued by the Ministers of Justice. Trying to contribute to the debate expert, this study asserts that, despite the perpetuation of slavery after the political independence of the country, many were the circumstances in which distinction between the freeman and the slave went not expressed.

Keywords: Slavery; Freedom; Imperial Brazil; Criminality. 
RICARDO ALEXANDRE FERREIRA

\section{NOTAS}

${ }^{1}$ A pesquisa que fundamentou o presente artigo foi desenvolvida com o apoio da Fundação de Amparo à Pesquisa do Estado de São Paulo FAPESP.

${ }^{2}$ Inúmeros estudos poderiam ser aqui citados, destaco dois por terem abordado delitos conceituados respectivamente como rebelião e insurreição, os quais compõem a parte II do Código Criminal de 1830, intitulada "Dos crimes públicos". São eles: MARSON, 1986 e REIS, 2003. ${ }^{3}$ A respeito do tema, Cf: AZEVEDO, 1987 e MACHADO, 1994.

4 Ao analisar o binômio "classes pobres, classes perigosas" em um debate parlamentar realizado na "Câmara dos Deputados do Império do Brasil nos meses que se seguiram à lei da abolição da escravidão, em maio de 1888", Sidney Chalhoub detecta, entre referências indiretas a autores estrangeiros que abordaram o tema desde meados do século XIX, uma racionalidade fria: "[...] os pobres carregam vícios, os vícios produzem os malfeitores, os malfeitores são perigosos à sociedade; juntando os extremos da cadeia, temos a noção de que os pobres são, por definição, perigosos. Por conseguinte, conclui decididamente a comissão, 'as classes pobres [...] são [as] que se designam mais propriamente sob o título de - classes perigosas - "'. CHALHOUB, 1996: 22. Para outras considerações do autor a respeito do mesmo tema, Cf. CHALHOUB, 1986.

5 Para uma visão geral da história do processo de desclassificação social no Ocidente, bem como da construção da categoria social do vadio no Brasil colonial, Cf: SOUZA, 2004. Especialmente "II - Da utilidade dos vadios".

${ }^{6}$ Um estudo que aborda os projetos de elaboração de estatísticas criminais no Brasil Imperial em comparação com suas congêneres francesas é: PIMENTEL FILHO, 2002.

${ }^{7}$ Não há aqui, do ponto de vista interpretativo, uma aceitação tácita do quadro da criminalidade composto pelos membros do executivo imperial, mas sim a oportunidade de compreender as transformações do cenário da segurança individual no Brasil oitocentista apresentado como crível aos legisladores, o qual por sua vez, acabava por integrar os principais debates nas casas de leis do Império. Durante algum tempo, a historiografia brasileira manifestou certo receio em lançar mão de documentos produzidos por instituições oficiais que compunham o 
LIVRES, ESCRAVOS E A CONSTRUÇÃO DE UM CONCEITO MODERNO...

aparato burocrático do Estado em estudos que se interessavam pela interpretação das ações de grupos tidos como marginais nas épocas em que viveram. Uma primeira transformação sofrida por essa cautela, de caráter teórico-metodológico, ocorreu no início dos anos 80 do século $\mathrm{XX}$ com o uso massivo e generalizado pelos historiadores de processoscrime como fontes, principalmente os produzidos no século XIX. No entanto, nos últimos anos, alguns estudos têm encontrado em outros conjuntos documentais provenientes do Poder Executivo um valioso contraponto para as interpretações que partem de recortes espacialmente localizados na tentativa de compreender, por um lado, os mecanismos de repressão e controle, e, por outro lado, as práticas e estratégias de alguns grupos sociais no cotidiano. Nessa linha de abordagem, que valoriza o estudo conjunto de processos criminais e relatórios oficiais, destacam-se: MACHADO, 1994; PIMENTEL FILHO, 2002 e VELLASCO, 2004.

${ }^{8}$ Embora já próximo do período de Conciliação (1853-1862) entre os partidos políticos imperiais, o próprio Pimenta Bueno deixou os liberais para, paulatinamente, juntar-se aos conservadores. Essa mudança, ocorrida entre os últimos anos da primeira e os primeiros da segunda metade dos oitocentos, precedeu sua nomeação para o cargo de Presidente da Província do Rio Grande do Sul (1850) e, posteriormente a eleição para ao cargo vitalício de Senador (1852) (KUGELMANS, 2002).

9 Entre as polêmicas jurídicas e políticas que envolveram a obra de Pimenta Bueno, destaca-se a da responsabilidade, ou não, dos Ministros de Estado pelos atos do Poder Moderador. Para Bueno as decisões do Poder Moderador eram privativas do Imperador. Porém, para outro estadista/jurista, Zacarias de Góis e Vasconcelos, os ministros também eram responsáveis pelos atos de tal poder, argumento defendido no seu Da Natureza e limites do Poder Moderador, cuja primeira edição data de 1860 e a segunda de 1862. No debate também se envolveu Paulino José Soares de Souza, o visconde do Uruguai, que combateu os argumentos de Zacarias na obra Ensaio sobre o Direito Administrativo (1862). Recorrentemente tomadas pela historiografia como um embate entre a leitura conservadora (Bueno e Uruguai) e a leitura liberal (Zacarias) da Constituição do Império, as obras referidas continuam despertando o interesse dos pesquisadores para o aprofundamento da compreensão dos matizes envolvidos na composição do Estado Imperial brasileiro. Cf: OLIVEIRA, 2002 e OLIVEIRA, 2003. 
RICARDO ALEXANDRE FERREIRA

${ }^{10}$ De acordo com José Murilo de Carvalho: No Império do Brasil, "embora houvesse distinção formal e institucional entre as tarefas judiciárias, executivas e legislativas, elas muitas vezes se confundiam na pessoa dos executantes, e a carreira judiciária se tornava parte integrante do itinerário que levava ao Congresso e aos conselhos de governo" (CARVALHO, 1996: 129).

${ }^{11}$ Dentre os mais de quarenta nomes que ocuparam o ministério até a abolição do cativeiro é possível destacar: Diogo Antonio Feijó (17841843) que foi responsável pelo relatório de 1831, Bernardo Pereira de Vasconcelos (1795-1850) que apresentou à Assembléia Geral o relatório de 1837, Paulino José Soares de Souza (1807-1866) responsável pelos relatórios de 1840 e pelo primeiro do ano de 1842, Eusébio de Queiroz Coutinho Mattoso Camara que apresentou os relatórios relativos aos anos 1849 e 1851, José Thomaz Nabuco de Araújo (1813-1878), um dos ministros que por mais tempo ocupou o cargo, figura como autor dos relatórios de 1853 a 1856 e também de 1865, Zacarias de Góis e Vasconcellos (1815-1877) que apresentou o segundo relatório relativo ano de 1863. Na lista de nomes que chefiaram a pasta da justiça figura também o do autor do romance $O$ Guarani (1857), José Martiniano de Alencar (1829-1877).

${ }^{12}$ O Poder Moderador foi definido pela Constituição de 1824. "Perdoar ou moderar as penas impostas a réus condenados por sentença (o direito de graça)" era apenas uma das várias atribuições concedidas ao seu detentor - o Monarca. A existência e as atribuições desse Quarto Poder foram motivos de constantes controvérsias e embates políticos nas diferentes fases do Império, mas o Poder Moderador não deixou de existir nem mesmo durante as regências. "Como, de acordo com a Constituição, o Poder Moderador era 'privativamente delegado' ao monarca, a abdicação de Pedro I levantou dúvidas sobre a legalidade ou não de os Regentes exercerem este Poder. Ficou estabelecido [pela lei de 14 de junho de 1831 que definiu o modo da Regência governar] que os regentes poderiam desempenhar todas as prerrogativas do Poder Executivo e todas as funções do Poder Moderador, 'com o referendo do ministro competente', excetuando-se apenas uma: a de dissolver a câmara dos deputados". Durante os debates em torno do Ato Adicional de 1834 os Liberais não conseguiram extinguir o Quarto poder, apenas o Conselho de Estado, o qual, por sua vez foi recriado pela lei de interpretação do Ato Adicional em 1841 (OLIVERIA, 2003: 147-148). 
LIVRES, ESCRAVOS E A CONSTRUÇÃO DE UM CONCEITO MODERNO...

${ }^{13}$ Entre os anos de 1824 e 1848 explodiram no Império do Brasil: "[...] levantes liberais de diferentes configurações políticas, organização e composição social: a Confederação do Equador, a Farroupilha, a Sabinada, a Revolução de 1842 em São Paulo e Minas e a Praieira. Por sua vez, os homens livres pobres e escravos aquilombados marcaram sua presença em insurreições como as Cabanadas do Pará e de Alagoas, a Balaiada, o Ronco da Abelha e o Quebra Quilos. E acompanhando esses episódios de maior projeção, é importante lembrar a atuação escrava, tanto nos enfrentamentos cotidianos e nas pequenas rebeliões quanto na revolta dos Malês na Bahia, em 1835" (MARSON,1998: 73). Para um panorama geral do período, ver também: CARVALHO, 1996. Especialmente,Teatro de sombras: a política imperial.

14 "Ataques contra a segurança da pessoa e vida 537 [50,1\%]. Contra a propriedade 271 [25,3\%]. De natureza mista 59 [5,5\%]. Fuga de presos, resistência e injúrias 130 [12,1\%]. Diversos outros crimes 75 [7,0\%]. Total 1072 [100 \%]". Relatório do Ministério da Justiça, doravante RMJ, (Ministro Bernardo Pereira de Vasconcelos) do ano de 1837, disponível na Internet na página eletrônica do Projeto de Imagens de Publicações Oficiais Brasileiras do "Center for Research Libraries e Latin American Microform Project", doravante PIPOB - CRL - LAMP, em: http://brazil.crl.edu/bsd/bsd/u1828/000008.html

e http://brazil.crl.edu/bsd/bsd/u1828/000009.html. Todas as fontes primárias, cujas imagens encontram-se armazenadas no sítio eletrônico do referido projeto, usadas na produção deste texto, foram pesquisadas selecionadas e impressas por mim entre janeiro e junho de 2005.

15 Excerto atribuído ao então (1837) Ministro da Justiça Bernardo Pereira de Vasconcelos, citado em: NABUCO, 1949, vol I: 43. Para um estudo mais amplo da trajetória de Bernardo Pereira de Vasconcelos Cf: CARVALHO, 1999.

${ }^{16}$ ALVES JÚNIOR, Thomaz. Anotações teóricas e práticas ao Código Criminal. Rio de Janeiro: Francisco Luiz Pinto \& C. editores, 1864. 4 tomos. Para uma detalhada descrição dos embates parlamentares que levaram à elaboração dos Códigos Criminal e do Processo Penal do Império. Cf. SLEIMAN, 2008.

${ }^{17}$ Realizei uma análise mais aprofundada dos fundamentos jurídicos imbricados na criação do Código de 1830 e de sua relação com a perpetuação do cativeiro no Brasil imperial em: FERREIRA, 2009. 
RICARDO ALEXANDRE FERREIRA

${ }^{18}$ Enquanto ao Código Criminal competia a conceituação dos crimes, criminosos e suas penas, cabia a outro código, o do Processo Penal de Primeira Instância promulgado em 1832, elaborado a partir de um projeto apresentado à Câmara dos Deputados por Manuel Alves Branco, a definição de todo o rito que validava a composição das peças que compunham o processo criminal, da formação da culpa até a realização dos julgamentos pelo Tribunal do Júri. Era o Código do Processo que definia as autoridades policiais, judiciárias sua hierarquia e competências, portanto ao longo do século ele recebeu duas reformas, a primeira em 1841 e a segunda em 1871, as quais serão tratadas a seguir. Código do Processo Criminal de Primeira Instancia do Império do Brasil com a Lei de 3 de dezembro de $1841 n^{\circ}$. 261, comentado e anotado pelo Conselheiro Vicente Alves de Paula Pessoa. Rio de Janeiro: Jacintho Ribeiro dos Santos Livreiro-Editor, 1899.

${ }^{19}$ RMJ (Ministro Gustavo Adolfo D'Aguilar Pantoja) do ano de 1836, PIPOB - $\quad$ CRL $\quad-\quad$ LAMP, em: http://brazil.crl.edu/bsd/bsd/u1827/000034.html.

${ }^{20}$ RMJ (Ministro Bernardo Pereira de Vasconcelos) do ano de 1837, PIPOB - $\quad$ CRL - $\quad$ LAMP, em: http://brazil.crl.edu/bsd/bsd/u1828/000012.html.

${ }^{21}$ De acordo com Thomas Flory: "The original law of 1827 had created a magistrate of primarily conciliatory and civil jurisdiction who nevertheless carried a certain coercive potential to mobilize local resistance to an absolutist threat. The Procedural Code reversed the order of precedence, deemphasizing the civil jurisdiction of de justice of the peace in favor of his criminal and police powers. After 1832 the 'juiz de paz' possessed authority to arrest wanted criminals in his or any other jurisdiction and to judge crimes for which the maximum penalty did not exceed a fine of 100 'mil réis' (\$77) and six month in the jail. More important, the Code gave the magistrate responsibility not only to assembling but also for determining cause for arraignment, arrest, and the bringing of charges (formação de culpa) in all crime proceedings. As the official responsible for bringing formal criminal charges, the parish judge stood at the base of the entire system of criminal justice" (FLORY, 1981: 64).

${ }^{22}$ RMJ (Ministro Bernardo Pereira de Vasconcelos) do ano de 1837, PIPOB - - CRL http://brazil.crl.edu/bsd/bsd/u1828/000015.html e http://brazil.crl.edu/bsd/bsd/u1828/000016.html. 
LIVRES, ESCRAVOS E A CONSTRUÇÃO DE UM CONCEITO MODERNO...

${ }^{23}$ Cf. FLORY, 1981. Especialmente, "The Jury System", p. 115-127.

${ }^{24}$ Código do Processo Criminal de Primeira Instancia do Império do Brasil com a Lei de 3 de dezembro de $1841 n^{\circ}$. 261, comentado e anotado pelo Conselheiro Vicente Alves de Paula Pessoa. Rio de Janeiro: Jacintho Ribeiro dos Santos Livreiro-Editor, 1899, p.45-54.

${ }^{25}$ RMJ (Ministro Bernardo Pereira de Vasconcelos) do ano de 1837, PIPOB - $\quad$ CRL $\quad-\quad$ LAMP, em: http://brazil.crl.edu/bsd/bsd/u1828/000015.html.

${ }^{26}$ Thomaz Flory defende a idéia de que as transformações da estrutura de competências policiais e judiciárias introduzidas pela reforma de 1841 do Código do Processo marcaram fundamentalmente uma fase de centralização política no Império do Brasil. "The 1841 law did indeed create a professional magistracy dependent upon the central government. The law's political essence derived from coercive ties of dependence - primarily the power of appointment - that bound the magisterial network to the government and gave the ministry ultimate control over its judicial representatives. Put simply, in return for his appointment and salary the magistrate would represent and make palatable the authority of his patron, the central government. This was dependence in the ideal sense, since it had no necessary partisan content" (FLORY, 1981: 184).

${ }^{27}$ Segundo o artigo 65 da reforma de 1841 do Código do Processo Criminal, nos limites de sua jurisdição territorial, o juiz de paz ainda possuía poderes para proceder a execução de exames de corpos de delito, reprimir os bêbados, os mendigos, os vadios e as 'meretrizes escandalosas, que perturbam o sossego público, obrigando-os a assinar termos de bem viver', destruir quilombos e vigiar para que novos não se formassem, prender os criminosos procurados e comunicar a outros juízes a prisão deles em seus distritos. Código do Processo Criminal op. cit, p. 390.

${ }^{28} \mathrm{O}$ cargo de juiz municipal não foi uma novidade da reforma de 1841. De acordo com o Código do Processo Criminal de 1832 o juiz municipal era escolhido a partir de uma lista tríplice composta por bacharéis em Direito, indicada pelas Câmaras Municipais. A partir de 1841, eles passaram a ser indicados pelo governo central, em geral pelos presidentes das províncias, e sua função judicial se misturou à policial, o que só se alterou com a reforma do Código do Processo Criminal de 1871.

HISTÓRIA, São Paulo, 28 (2): 2009 
RICARDO ALEXANDRE FERREIRA

${ }^{29}$ Código do Processo Criminal de Primeira Instancia do Império do Brasil com a Lei de 3 de dezembro de $1841 n^{\circ}$. 261, comentado e anotado pelo Conselheiro Vicente Alves de Paula Pessoa. Rio de Janeiro: Jacintho Ribeiro dos Santos Livreiro-Editor, 1899, p. 430.

${ }^{30}$ Cf. Capítulo III da Reforma do Código do Processo Criminal de 1841, artigos 223 a 239. Código do Processo Criminal de Primeira Instancia do Império do Brasil com a Lei de 3 de dezembro de $1841 n^{\circ}$. 261, comentado e anotado pelo Conselheiro Vicente Alves de Paula Pessoa. Rio de Janeiro: Jacintho Ribeiro dos Santos Livreiro-Editor, 1899, p. 429-434.

${ }^{31}$ RMJ (Ministro Eusébio de Queiroz Coutinho Mattoso Camara) do ano de 1849, PIPOB - $\quad$ CRL http://brazil.crl.edu/bsd/bsd/u1841/000006.html. Grifos nossos.

${ }^{32}$ Segundo o jurista Vicente Alves de Paula Pessoa as leis que reformaram o Código do Processo Criminal de primeira instância de 1832 assim se sucederam: "Foi reformado em muitas partes pela Lei $n^{\circ} 260$ de 3 de Dezembro de 1841, para cuja execução se deram os regulamentos de 31 de janeiro de 1842, 2 fevereiro e 15 de março do mesmo ano. Ainda tivemos novas reformas, pela Lei $\mathrm{n}^{\circ} 2033$ de 20 de setembro de 1871, e Regulamento $\mathrm{n}^{\circ} 4824$ de 22 de novembro do mesmo ano; não sendo vicioso citar como reformas o Decreto $n^{\circ} 5456$ de 5 de novembro de 1873, que contém providencias e medidas transitórias para a instalação de novas relações, que são sete, criadas pelo Decreto $n^{\circ} 2342$ de 6 de agosto de 1873. O Decreto $n^{\circ} 5485$ de 7 de novembro de 1873, declarando especiais as comarcas sedes das Relações. O de no 5467 de 12 de novembro de 1873, dando Regulamento para a interposição dos agravos e apelações cíveis. $\mathrm{O}$ de $\mathrm{n}^{\circ} 5618$ de 2 de maio de 1874, dando novo Regulamento às Relações do Império". Código do Processo Criminal de Primeira Instancia do Império do Brasil com a Lei de 3 de dezembro de $1841 n^{\circ}$. 261, comentado e anotado pelo Conselheiro Vicente Alves de Paula Pessoa. Rio de Janeiro: Jacintho Ribeiro dos Santos Livreiro-Editor, 1899, p. 7.

${ }^{33}$ Em seu Estadista do Império, Joaquim Nabuco assim descreve a seqüência de projetos de reforma do judiciário produzidos pelos ministros da Justiça entre a lei de 1841 e a lei de 1871: “... em 1846 e 1848 (situação liberal) propostas de [José Joaquim] Fernandes Torres e [José Antonio] Pimenta Bueno; em 1854, projeto de [José Thomaz Nabuco [de Araujo] (ministério Paraná); em 1858, projeto substitutivo de [Francisco] Diogo [Pereira] de Vasconcelos; em 1862, proposta de [João Lins Vieira Cansansão de] Sinimbu; em 1866, proposta de [José Thomaz Nabuco [de Araujo]. Em 1861, [Francisco de Paula de Negreiros] Saião Lobato preparou um projeto de reforma que foi impresso e distribuído, mas não chegou a ser apresentado à Câmara" (NABUCO, 1949, vol III: 236). 
LIVRES, ESCRAVOS E A CONSTRUÇÃO DE UM CONCEITO MODERNO...

${ }^{34}$ Para uma análise específica dos debates em torno da Reforma de 1871, Cf: CERQUEIRA LEITE,1982.

${ }^{35}$ RMJ (Ministro Francisco Ramiro D'Assis Coelho) do ano de 1839, PIPOB CRL - LAMP, em: http://brazil.crl.edu/bsd/bsd/u1830/000044.html.

${ }^{36}$ RMJ (Ministro Paulino José Soares de Souza) do ano de 1840, PIPOB CRL - LAMP, em: http://brazil.crl.edu/bsd/bsd/u1831/000019.html. Grifo nosso.

${ }^{37}$ Mais que isso, Paulino era membro, ao lado de Joaquim José Rodrigues Torres (futuro Visconde de Itaboraí) e Euzébio de Queirós, da trindade Saquarema, núcleo fundamental na direção do Partido Conservador no período chave do processo de construção do Estado no Império do Brasil. Cf. MATTOS, 1994.

${ }^{38}$ RMJ (Ministro Paulino José Soares de Souza) do ano de 1840, PIPOB CRL - LAMP, em: http://brazil.crl.edu/bsd/bsd/u1831/000025.html.

${ }^{39}$ RMJ (Ministro Manuel Alves Branco) do ano de 1843, PIPOB - CRL LAMP, em: http://brazil.crl.edu/bsd/bsd/u1834/000008.html.

40 Para uma análise ampla do binômio "violência-família", no período compreendido entre as duas últimas décadas do período colonial e meados dos oitocentos, no Ceará, Cf.: VIEIRA JÚNIOR, 2002.

${ }^{41}$ RMJ (Ministro José Joaquim Fernandes Torres) do ano de 1846, PIPOB CRL - LAMP, em http://brazil.crl.edu/bsd/bsd/u1838/000015.html.

${ }^{42}$ RMJ (Ministro José Antônio Pimenta Bueno) do ano de 1847, PIPOB CRL - LAMP, em http://brazil.crl.edu/bsd/bsd/u1839/000014.html.

${ }^{43}$ No período compreendido entre os anos de 1853 e 1862 inicia-se com o Gabinete ministerial presidido por Honório Hermeto Carneiro de Leão (Marquês do Paraná) uma política de conciliação entre os Partidos Liberal e Conservador em nome da integridade do Império. Nas palavras de Joaquim Nabuco "durante, pode se dizer, dez anos antigos Liberais e antigos Conservadores vão aparecer misturados nos mesmos gabinetes, até que com a formação do Partido Progressista os conservadores puros se extremam outra vez e de novo recomeça o antagonismo dos partidos". (NABUCO, 1949, vol. I: 176). É para caracterizar esse período que Joaquim Nabuco cita a famosa frase de Holanda Cavalcanti: "'Não há nada mais parecido com um Saquarema que um Luzia no poder', era a verdade sentida por todos", completa Nabuco. (NABUCO, 1949, vol. I: 174). Ver também: MARSON, 1986. Especialmente, o capítulo: "O império do progresso".

${ }^{44}$ RMJ (Ministro José Thomaz Nabuco de Araújo) do ano de 1855, PIPOB CRL - LAMP, em http://brazil.crl.edu/bsd/bsd/u1847/000007.html.

${ }^{45}$ Para um detalhado estudo deste recenseamento, Cf. BOTELHO, 1998. 
RICARDO ALEXANDRE FERREIRA

${ }^{46}$ Refiro-me aqui sempre aos delitos que chegaram à fase de inquérito policial e aos que se tornaram processos criminais. Os padrões obtidos a partir dos números de prisões, principalmente em centros urbanos como o Rio de Janeiro, por exemplo, demonstram por vezes percentuais significativos de crimes contra a ordem pública ou contra a propriedade. Cf: ALGRANTI, 1988.

${ }^{47}$ Relatório dos Presidentes da Província de São Paulo, doravante RPPSP (Presidente José Thomas Nabuco de Araújo) do ano de 1852, PIPOB - CRL LAMP.

${ }^{48}$ RPPSP (Presidente Antonio da Costa Pinto Silva) do ano de 1871, PIPOB CRL - LAMP, em http://brazil.crl.edu/bsd/bsd/1012/000152.html até http://brazil.crl.edu/bsd/bsd/1012/000159.html.

${ }^{49}$ RPPSP (Presidente Antonio da Costa Pinto Silva) do ano de 1871, PIPOB CRL - LAMP, em http://brazil.crl.edu/bsd/bsd/1012/000142.html até http://brazil.crl.edu/bsd/bsd/1012/000147.html.

${ }^{50}$ Descrições detalhadas dos crimes mencionados, envolvendo escravos, libertos e livres, relatados tanto pelos ministros da justiça, quanto pelos presidentes da Província de São Paulo no século XIX, podem ser consultadas em: FERREIRA, 2006.

${ }^{51} \mathrm{O}$ tráfico interprovincial no Brasil existia antes de 1850. Foi, entretanto, após esta data que se adensou o envio de escravos, principalmente, das províncias do Nordeste para o Centro Sul. No entanto, em 1871, preocupados com o grande contingente de escravos rapidamente transferidos para a Província de São Paulo, os representantes dos senhores de escravos propuseram na Assembléia Provincial taxações sobre a importação que culminaram no significativo encarecimento dos cativos. $O$ debate se seguiu no restante do país. Entre fins de 1880 e início de "1881 as províncias de São Paulo, Minas Gerais e Rio de Janeiro criaram impostos de tal monta que virtualmente proibiam a importação de escravos de outras províncias, assim pondo fim ao tráfico interprovincial de seres humanos [...] Finalmente, em 1885 uma lei foi aprovada libertando todos os escravos transferidos de uma província para outra" (GRAHAM, 2002: 140-141).

${ }^{52}$ Para os principais debates a respeito da vinculação entre o movimento interprovincial de cativos do nordeste para o centro-sul e o aumento da criminalidade escrava nas áreas exportadoras do Rio de Janeiro e de São Paulo na segunda metade dos oitocentos, Cf: AZEVEDO, 1987; CHALHOUB, 1990; MACHADO, 1987 e 1994; MATTOS, 1998 e FERREIRA, 2005.

Artigo recebido em 08/2009. Aprovado em 10/2009. 